\title{
Biochemical metabolism of young plants of Ucuúba (Virola surinamensis) in the presence of cadmium
}

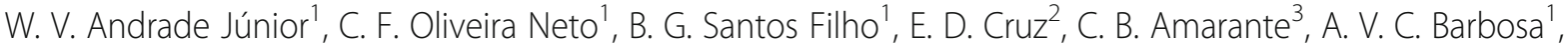 \\ G. A. S. Nogueira ${ }^{1,4^{*}}$ (D) V. R. Nascimento ${ }^{1}$, D. J. P. Sousa ${ }^{1}$ and J. S. S. Teixeira ${ }^{1}$
}

\begin{abstract}
Virola surinamensis is a forest species widely distributed in the estuaries of the Amazon. These ecosystems are susceptible to contamination by Cadmium (Cd), indicating that the plant has strategies for tolerating this metal. The aim of this study was to assess the nitrogen and carbon metabolism of young plants of Ucuúba (Virola surinamensis) in the presence of cadmium with the perspective of the phytoremediation of contaminated environments. The used experimental design was a completely randomized design with five $\mathrm{Cd}$ concentrations $(0$, $15,30,45$, and $60 \mathrm{mg} \mathrm{L}^{-1}$ ), for 60 days. In general, Cd did not affect nitrate concentration in the root but had a positive effect on leaves. The reduction of nitrate reductase (NR) in plants exposed to $\mathrm{Cd}$ was followed by a decrease in ammonia, total soluble amino acids (TSA), and total soluble proteins (TSP). Cd promoted an increase in the concentration of total soluble carbohydrates (TSC), proline, sucrose, and reducing sugars in the plants. The increase in TSC, sucrose and proline, suggests a metabolic regulatory mechanism of $V$. surinamensis against Cd stress.
\end{abstract}

Keywords: Nitrate reductase, Total soluble carbohydrates, Proline, Sucrose, Reducing sugars

\section{Background}

Increased cadmium $(\mathrm{Cd})$ concentration in the environment, caused especially by mining residues and excessive use of phosphate fertilizers, promotes serious imbalances in terrestrial and aquatic ecosystems because it is highly toxic and persistent in the environment, as well as present a high mobility in the soil for plants, being incorporated and bioaccumulated to other components of the food chain, rapidly affecting the growing number of organisms [1].

High levels of $\mathrm{Cd}$ in the soil commonly causes many stress symptoms in plants such alterations in the concentration of starch and soluble carbohydrates in

\footnotetext{
* Correspondence: glauand@yahoo.com.br

${ }^{1}$ Federal Rural University of the Amazon, Institute of Agronomists Sciences, Campus Belém, Belém, Pará, Brazil

${ }^{4}$ Federal Rural University of the Amazon, Institute of Agronomists Sciences, Campus Parauapebas, Parauapebas, Pará, Brazil

Full list of author information is available at the end of the article
}

plants tissues [2, 3]. The lower nitrate absorption $\left(\mathrm{NO}_{3}{ }^{-}\right)[4,5]$, changes in nitrate reductase (NR) activity [6], proline [5, 7], total soluble proteins (PST) and total soluble amino acids (TSA) [8] in plants under the effect of $\mathrm{Cd}$ have also been observed.

It has been postulated that higher plants are more sensitive to Cd stress [9]. However, study conducted by Andrade Júnior et al. [10] demonstrated medium and high tolerance of Virola surinamensis to Cd. Variations in $\mathrm{Cd}$ tolerance in plants may be associated with changes in nitrogen and or carbon metabolism. Differential Cd tolerance can be attributed to differential accumulation of amino acids such as proline, and sugars, which serve as compatible osmolytes and antioxidants or are involved in other plant defense pathways against stress [9].

$V$. surinamensis (Ucuúba) a forest species with economic and medicinal interest, besides being useful for recomposition of altered areas. Is a species widely distributed and 
adapted to the lowland and igapó ecosystems in the Amazon [10] These ecosystems are constantly susceptible to heavy metal contamination, as $\mathrm{Cd}$ [11-13], indicating that the plant has strategies to tolerate environments contaminated by these metals.

Recent study showed that, in addition to tolerance to $\mathrm{Cd}, V$. surinamensis had a greater ability to extract and accumulate metal in the root, restricting its transport to the aerial part [10]. Species with these characteristics are promising for phytostabilization of metals. Thus, we tested the hypothesis that $V$. surinamensis develops biochemical strategies capable of tolerating and accumulate high $\mathrm{Cd}$ concentrations. Thus, this study aimed to assess the nitrogen and carbon metabolism of young plants of $V$. surinamensis in the presence of cadmium, in order to contribute to understand the potential of $V$. surinamensis against $\mathrm{Cd}$ stress.

\section{Results}

Effect of cd on the concentrations of nitrate, nitrate reductase, and free ammonium

Nitrate concentrations in the roots were not significantly affected by $\mathrm{Cd}$, except for the dose of $15 \mathrm{mg} \mathrm{L}^{-1}$ of $\mathrm{Cd}$
(Fig. 1a). In the leaves, nitrate concentrations were significantly affected by $\mathrm{Cd}$ (Fig. 1b). In the roots, $\mathrm{Cd}$ concentrations reached 0.045 and $0.04 \mu \mathrm{mol} \mathrm{NO}_{3}{ }^{-} \mathrm{g}^{-1}$ $\mathrm{DM}$ in the control treatment $\left(0 \mathrm{mg} \mathrm{L}^{-1}\right.$ of $\left.\mathrm{Cd}\right)$ and at a dose of $15 \mathrm{mg} \mathrm{L}^{-1}$ of $\mathrm{Cd}$, respectively (Fig. 1a), corresponding to a reduction of $11.11 \%$ when compared to the control. In the leaves, values of 0.01 and $0.02 \mu \mathrm{mol}$ $\mathrm{NO}_{3}{ }^{-} \mathrm{g}^{-1}$ DM were obtained in the control plants $(0$ $\mathrm{mg} \mathrm{L}^{-1}$ of $\left.\mathrm{Cd}\right)$ and at the highest dose of $\mathrm{Cd}\left(60 \mathrm{mg} \mathrm{L}^{-1}\right.$ of $\mathrm{Cd}$ ), respectively (Fig. 1b), characterizing an increase of $100 \%$ in the treatment of $60 \mathrm{mg} \mathrm{L}^{-1}$ of $\mathrm{Cd}$ when compared to the control treatment.

The nitrate reductase activity (NRA) was significantly affected by $\mathrm{Cd}$, both in roots and leaves (Fig. 1c, d). In the roots, the lowest value $\left(0.33 \mu \mathrm{mol} \mathrm{NO}_{2}^{-} \mathrm{g}^{-1} \mathrm{FM}\right.$ $\mathrm{h}^{-1}$ ) was observed at a dose of $60 \mathrm{mg} \mathrm{L}^{-1}$ of Cd, representing a $56 \%$ reduction when compared to the control treatment $\left(0.76 \mu \mathrm{mol} \mathrm{NO}{ }_{2}^{-} \mathrm{g}^{-1} \mathrm{FM} \mathrm{h}^{-1}\right)$ (Fig. 1c). The reduction was more accentuated in the leaves, reaching a value of $0.02 \mu \mathrm{mol} \mathrm{NO}{ }_{2}^{-} \mathrm{g}^{-1} \mathrm{FM} \mathrm{h}^{-1}$ at a dose of 60 $\mathrm{mg} \mathrm{L}^{-1}$ of $\mathrm{Cd}$, corresponding a decrease of $97.47 \%$ when compared to the control treatment $\left(0.79 \mu \mathrm{mol} \mathrm{NO}{ }_{2}^{-} \mathrm{g}^{-1}\right.$ $\mathrm{FM} \mathrm{h}^{-1}$ ) (Fig. 1d).
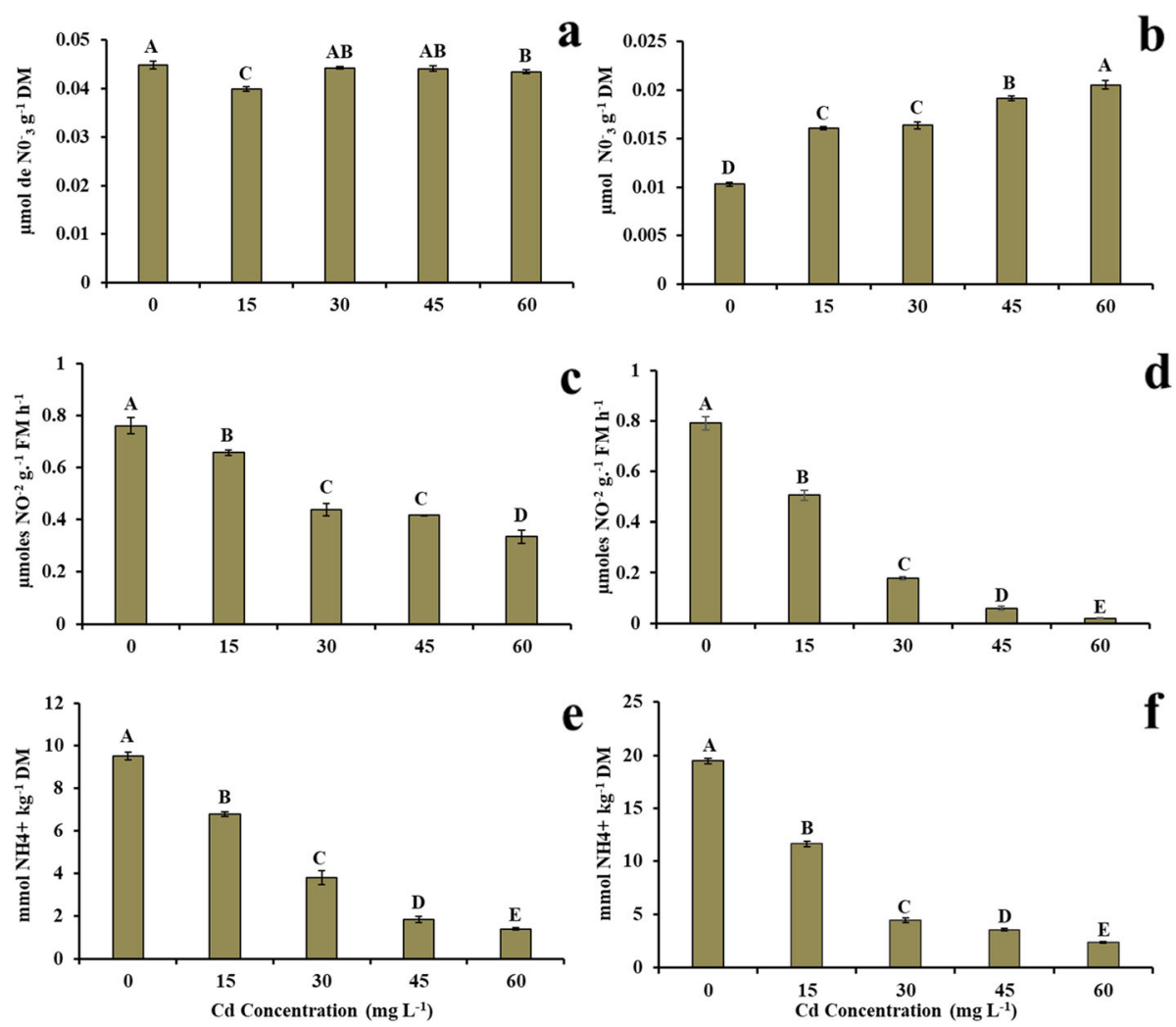

Fig. 1 a Nitrate concentration in the root, $\mathbf{b}$ nitrate concentration in the leaves, $\mathbf{c}$ nitrate reductase concentration in the root, $\mathbf{d}$ nitrate reductase concentration in the leaves, $\mathbf{e}$ ammonium concentration in the root, $\mathbf{f}$ ammonium concentration in the leaves in young plants of $\mathbf{V}$. surinamensis exposed to five cadmium concentrations $(0,15,30,45$, and $60 \mathrm{mg})$. Different letters for cadmium concentrations in solution indicate significant differences in the Tukey's test $(P<0.05)$. Mean $\pm S D, n=7$ 
Cd significantly affected free ammonia, both in roots and leaves (Fig. 1e, f). In the roots, values of $9.52 \mathrm{mmol}$ $\mathrm{NH}_{4}{ }^{+} \mathrm{kg}^{-1} \mathrm{DM}\left(0 \mathrm{mg} \mathrm{L}^{-1}\right.$ of $\left.\mathrm{Cd}\right)$ and $1.39 \mathrm{mmol}$ of $\mathrm{NH}_{4}{ }^{+} \mathrm{kg}^{-1} \mathrm{DM}\left(60 \mathrm{mg} \mathrm{L}^{-1}\right.$ of $\left.\mathrm{Cd}\right)$ were obtained, representing a $85.4 \%$ reduction at the highest dose of $\mathrm{Cd}$ when compared to the control treatment (Fig. 1e). In the leaves, $\mathrm{Cd}$ effect was more significant, promoting a reduction of $87.77 \%$ in ammonia concentration at a dose of $60 \mathrm{mg} \mathrm{L}^{-1}$ of $\mathrm{Cd}\left(2.38 \mathrm{mmol}\right.$ of $\left.\mathrm{NH}_{4}{ }^{+} \mathrm{kg}^{-1} \mathrm{DM}\right)$ when compared to the control treatment $\left(19.47 \mathrm{mmol}^{\circ} \mathrm{NH}_{4}{ }^{+}\right.$ $\left.\mathrm{kg}^{-1} \mathrm{DM}\right)$ (Fig. 1f).

Effect of cd on the concentrations of total soluble amino acids, total soluble proteins and proline concentration

The concentration of total soluble amino acids in roots and leaves was significantly affected by Cd (Fig. 2). In the roots, the concentration was 330 and $243 \mu \mathrm{mol}$ AA $\mathrm{g}^{-1} \mathrm{DM}$ in the control treatment $\left(0 \mathrm{mg} \mathrm{L}^{-1}\right.$ of $\left.\mathrm{Cd}\right)$ and at a dose of $60 \mathrm{mg} \mathrm{L}^{-1}$ of Cd, respectively (Fig. 2a), corresponding to a reduction of $26.36 \%$ at the highest $\mathrm{Cd}$ dose when compared to the control treatment. In the leaves, values of 337 and $215 \mu \mathrm{mol} \mathrm{AA} \mathrm{g}{ }^{-1} \mathrm{DM}$ were obtained in the control plants $\left(0 \mathrm{mg} \mathrm{L}^{-1}\right.$ of $\left.\mathrm{Cd}\right)$ and at the highest $\mathrm{Cd}$ dose $\left(60 \mathrm{mg} \mathrm{L}^{-1}\right.$ of $\mathrm{Cd}$ ), respectively (Fig. $\left.2 \mathrm{~b}\right)$, characterizing a $36.2 \%$ reduction in the treatment of $60 \mathrm{mg}$ $\mathrm{L}^{-1}$ of $\mathrm{Cd}$ when compared to the control treatment.

The concentrations of total soluble proteins in plants submitted to the presence of $\mathrm{Cd}$ were significantly reduced in both roots and leaves (Fig. 2c, d). The highest and lowest concentrations of proteins in roots occurred in the control treatment $\left(0.54 \mathrm{mg}\right.$ protein $\left.\mathrm{g}^{-1} \mathrm{DM}\right)$ and at a dose of $60 \mathrm{mg} \mathrm{L}^{-1}$ of $\mathrm{Cd}\left(0.35 \mathrm{mg}\right.$ protein $\left.\mathrm{g}^{-1} \mathrm{DM}\right)$, with a $35.18 \%$ reduction at the highest $\mathrm{Cd}$ dose when compared to the control treatment (Fig. 2c). In the leaves, the values obtained were $0.37 \mathrm{mg}$ protein $\mathrm{g}^{-1}$ DM (control treatment) and $0.15 \mathrm{mg}$ protein $\mathrm{g}^{-1} \mathrm{DM}$ $\left(60 \mathrm{mg} \mathrm{L}^{-1}\right.$ of $\mathrm{Cd}$ ), corresponding to a decrease of $59.46 \%$ in the lowest $\mathrm{Cd}$ dose when compared to the control treatment (Fig. 2d).

Proline concentrations in roots and leaves of plants submitted to $\mathrm{Cd}$ doses increased significantly (Fig. 2). Values of $0.60 \mu \mathrm{mol}$ Pro $\mathrm{g}^{-1} \mathrm{DM}\left(0 \mathrm{mg} \mathrm{L}^{-1}\right.$ of $\left.\mathrm{Cd}\right)$ and $0.76 \mu \mathrm{mol}$ Pro $\mathrm{g}^{-1} \mathrm{DM}\left(60 \mathrm{mg} \mathrm{L}^{-1}\right.$ of $\left.\mathrm{Cd}\right)$ were obtained in the roots, representing a $26.7 \%$ increase at the highest $\mathrm{Cd}$ dose when compared to the control treatment (Fig. 2e). In the leaves of control plants and at a dose of $60 \mathrm{mg} \mathrm{L}^{-1}$ of
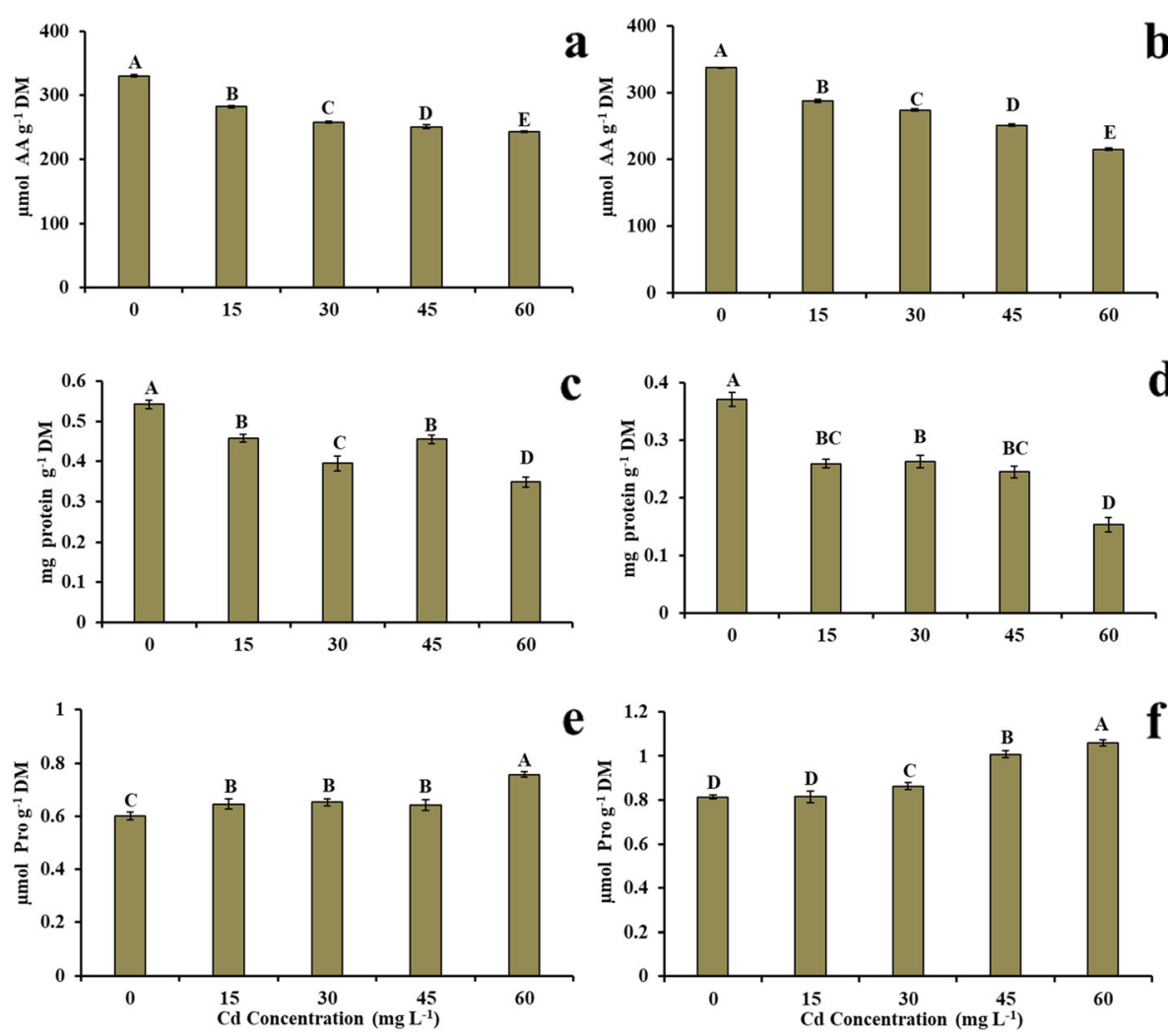

Fig. 2 a Concentration of total soluble amino acids in the root, $\mathbf{b}$ concentration of total soluble amino acids in the leaves, c concentration of total soluble proteins in the root, $\mathbf{d}$ concentration of total soluble proteins in the leaves, e Proline concentration in the root, $\mathbf{f}$ proline concentration in the leaves in young plants of $V$. surinamensis exposed to five cadmium concentrations $(0,15,30,45$, and $60 \mathrm{mg})$. Different letters for cadmium concentrations in solution indicate significant differences in the Tukey's test $(P<0.05)$. Mean $\pm S D, n=7$ 
$\mathrm{Cd}$, proline concentrations were 0.81 and $1.06 \mu \mathrm{mol}$ Pro $\mathrm{g}^{-1} \mathrm{DM}$, respectively, demonstrating a $30.86 \%$ increase of proline in plants with the highest $\mathrm{Cd}$ dose when compared to the control treatment (Fig. 2f).

\section{Concentration of total soluble carbohydrates, sucrose, and reducing sugars in the presence of $\mathrm{cd}$}

The concentrations of total soluble carbohydrates in Cdtreated plants increased significantly in both roots and leaves (Fig. 3a, b). The lowest and highest concentrations of carbohydrates in the roots were observed in the control treatment $\left(0.06 \mathrm{mmol} \mathrm{Glu} \mathrm{g}^{-1}\right)$ and at a dose of 60

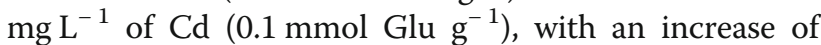
83.3\% at the highest $\mathrm{Cd}$ dose when compared to the control treatment (Fig. 3a). In the leaves, the obtained values were $0.09 \mathrm{mmol} \mathrm{Glu} \mathrm{g}^{-1}$ (control treatment) and $0.1 \mathrm{mmol} \mathrm{Glu} \mathrm{g}{ }^{-1}$ ( $15 \mathrm{mg} \mathrm{L}^{-1}$ of $\mathrm{Cd}$ ), corresponding to an $11.11 \%$ increase at the lowest $\mathrm{Cd}$ dose when compared to the control treatment (Fig. 3b).

Sucrose concentrations in Cd-treated plants increased significantly in both roots and leaves (Fig. 3c, d). In the roots, the values were $1.16 \mathrm{mg}$ sucrose $\mathrm{g}^{-1} \mathrm{DM}(0 \mathrm{mg}$ $\mathrm{L}^{-1}$ of $\left.\mathrm{Cd}\right)$ and $2.11 \mathrm{mg}$ sucrose $\mathrm{g}^{-1} \mathrm{DM}\left(60 \mathrm{mg} \mathrm{L}^{-1}\right.$ of
Cd), representing an increase of $81.9 \%$ at the highest $\mathrm{Cd}$ dose when compared to the control treatment (Fig. 3c). The lowest and highest concentrations of sucrose in the leaves were observed in the control treatment $(0.57 \mathrm{mg}$ sucrose $\left.\mathrm{g}^{-1} \mathrm{DM}\right)$ and at a dose of $60 \mathrm{mg} \mathrm{L}^{-1}$ of $\mathrm{Cd}(2.38 \mathrm{mg}$ sucrose $\mathrm{g}^{-1} \mathrm{DM}$ ), with a $317.54 \%$ increase at the highest $\mathrm{Cd}$ dose when compared to the control treatment (Fig. 3d).

The concentrations of reducing sugars increased in the roots and reduced significantly in the leaves of plants submitted to the presence of $\mathrm{Cd}$ (Fig. 3e, f). Values of

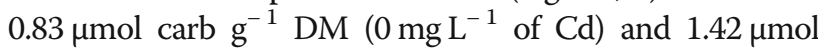
carb g ${ }^{-1} \mathrm{DM}\left(45 \mathrm{mg} \mathrm{L}^{-1}\right.$ of Cd) were obtained in the roots, representing a $71.08 \%$ increase at a dose of $45 \mathrm{mg} \mathrm{L}^{-1}$ of $\mathrm{Cd}$ when compared to the control treatment (Fig. 3e). The concentrations in the leaves of control plants and at a dose of $15 \mathrm{mg} \mathrm{L}^{-1}$ of $\mathrm{Cd}$ were 1.57 and $1.27 \mu \mathrm{mol}$ carb g $^{-1} \mathrm{DM}$, respectively, demonstrating a $19.11 \%$ reduction of reducing sugars in plants with the lowest $\mathrm{Cd}$ dose when compared to the control treatment (Fig. 3f).

\section{Discussion}

$\mathrm{NO}_{3}{ }^{-}$, an important $\mathrm{N}$ source, is actively absorbed by the plasma membrane of epidermal and cortical cells of
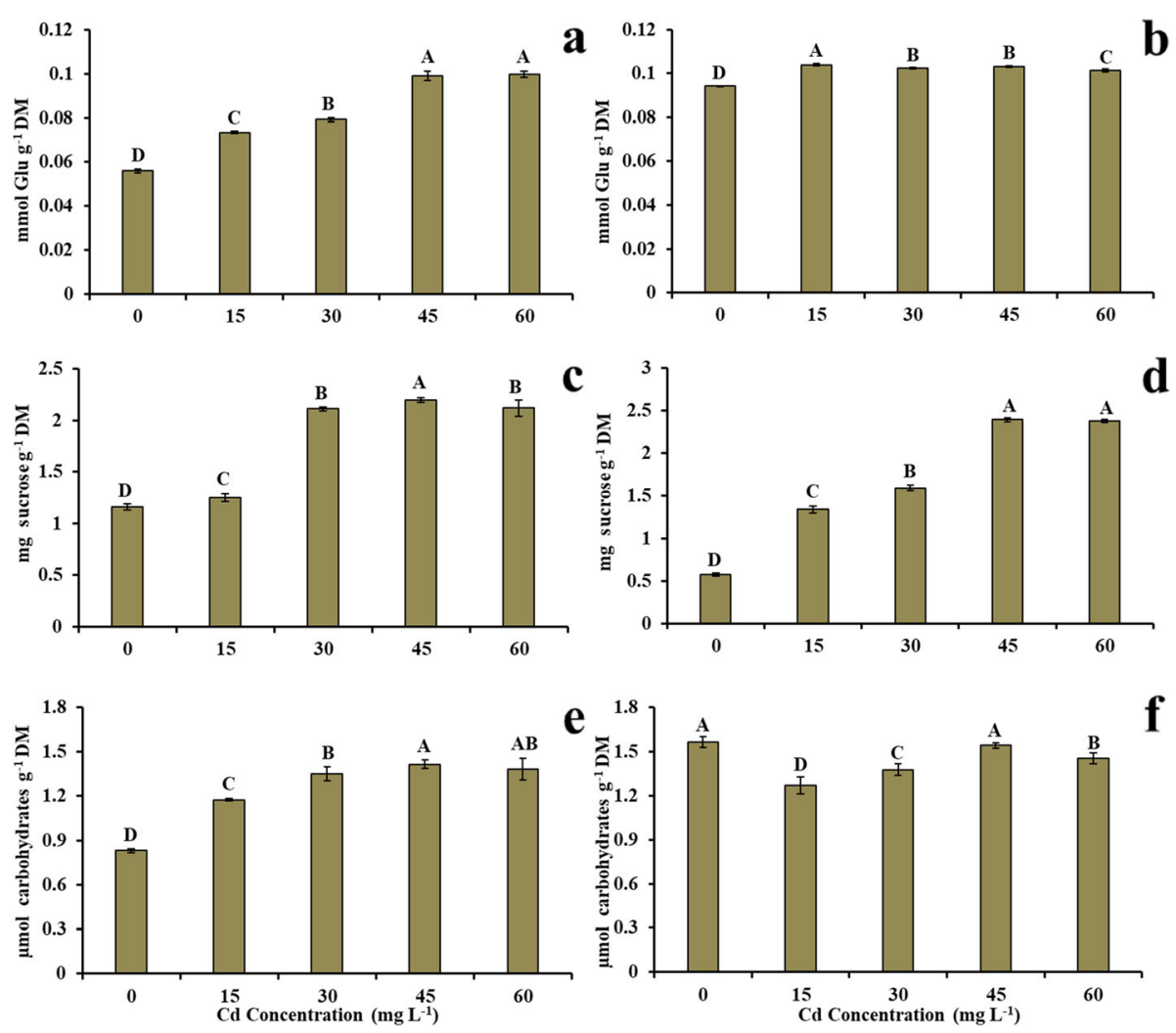

Fig. $\mathbf{3}$ a Concentration of total soluble carbohydrates in the root, $\mathbf{b}$ concentration of total soluble carbohydrates in the leaves, $\mathbf{c}$ sucrose concentration in the root, $\mathbf{d}$ sucrose concentration in the leaves, e concentration of reducing sugars in the root, $\mathbf{f}$ concentration of reducing sugars in the leaves in young plants of $V$. surinamensis exposed to five cadmium concentrations $(0,15,30,45$, and $60 \mathrm{mg})$. Different letters for cadmium concentrations in solution indicate significant differences in the Tukey's test $(P<0.05)$. Mean $\pm \mathrm{SD}, n=7$ 
roots through nitrate carrier proteins, but in plants exposed to $\mathrm{Cd}$, there is an inhibition of the activities of these proteins [14] because $\mathrm{Cd}$ damages the normal function of the proton pump $\left(\mathrm{H}^{+}\right.$ATPase $)$in the plasmalemma $[15,16]$. However, in general, no reduction of $\mathrm{NO}_{3}{ }^{-}$was observed in the roots of $V$. surinamensis (Fig. 1a), indicating that the presence of Cd probably did not affect the activity of $\mathrm{NO}_{3}{ }^{-}$carrier proteins, which is in accordance with the study performed by [17], who showed an increase of the total ATPase in the root and stem of Cucumis sativus in the presence of $\mathrm{Cd}$.

In healthy plants, once absorbed by roots, $\mathrm{NO}_{3}{ }^{-}$is transported to the leaves, stored in the vacuoles or reduced into nitrite $\left(\mathrm{NO}_{2}{ }^{-}\right)$by $\mathrm{NAD}(\mathrm{P}) \mathrm{H}$-dependent cytosolic NR activity [18]. In this study, the increase of $\mathrm{NO}_{3}{ }^{-}$in the leaves of $V$. surinamensis (Fig. 1b) suggests that $\mathrm{Cd}$ did not interfere with the translocation of the nitrogen compound to the shoot. The assimilation of $\mathrm{NO}_{3}{ }^{-}$into the cytosol of mesophyll cells may have been affected by the NRA inactivation caused by $\mathrm{Cd}$. The reduction of NRA with the increasing $\mathrm{Cd}$ doses in the nutrient solution may be an efficient energy-saving mechanism to reduce the effect of stress and not to decrease $\mathrm{NO}_{3}{ }^{-}$in the plant.

$\mathrm{NR}$ is the key enzyme in the process of $\mathrm{NO}_{3}{ }^{-}$assimilation [5] and is regulated by the presence of $\mathrm{NO}_{3}{ }^{-}$[19], its degradation, activation or inactivation. Plants exposed to $\mathrm{Cd}$ have a reduced NRA, leading to a decreased $\mathrm{NO}_{3}{ }^{-}$ assimilation because the metal causes a lower $\mathrm{NO}_{3}{ }^{-}$absorption by plant roots $[4,5]$. In this study, the marked reduction of NRA with the increasing $\mathrm{Cd}$ concentration (Fig. 1c) did not appear to have been caused by substrate availability $\left(\mathrm{NO}_{3}{ }^{-}\right)$since there was no reduction of the nitrogen compound in the plant root and shoot, suggesting a direct effect of $\mathrm{Cd}$ on NR activity, i.e. the interaction of the metal with the thiol group $(-\mathrm{SH})$ in the active site of the enzyme would result in the inactivation. Reduction of nitrate reductase activity was also observed in other tree species [5] exposed to Cd.

Ammonium ion is a central intermediate in the metabolism of nitrogen in plant, produced during nitrate assimilation, deamination of amino acids and photorespiration [20]. Considering that from ammonia, there are several biosynthesis routes for all amino acids [21], it can be inferred that in this study, the decrease in ammonia levels (Fig. 1e, f), in plants under $\mathrm{Cd}$, it may be related to the reduction of TSA (Fig. 2a, b) or to the increase in the synthesis of specific amino acids, of protection and stress regulation, such as proline (Fig. 2e, f).

$\mathrm{Cd}$ stress in plants causes protein degradation and affects amino acid metabolism [22]. The reduction in TSP (Fig. 2c, d) in $V$. surinamensis under $\mathrm{Cd}$ may be due to the activation of proteases that degrade proteins for specific amino acid biosynthesis such as proline (Fig. 2e, f). Thus, the degradation of TSP could function as an important mechanism of self-protection and / or cell signaling against $\mathrm{Cd}$ stress. Another explanation for the reduction of TSP in plants exposed to $\mathrm{Cd}$ would be the direct effect of the metal on the NRA that affected concentration of TSP. In fact, a significant positive correlation coefficient $(r=0.784 ; p=0.0367)$ was observed between these variables in plants under $\mathrm{Cd}$, ie the decrease in TSP in $V$. surinamensis under $\mathrm{Cd}$ would be associated with a reduction in NRA. The results obtained in present study in relation the total soluble proteins were evidenced by Anand et al. [23].

The highest proline content in plants exposed to $\mathrm{Cd}$ occurred by de novo synthesis or decreased degradation and/or both processes [24]. In this study, the increase of proline (Fig. 2a, b) in plants in the presence of $\mathrm{Cd}$ may be related to $\mathrm{NO}_{3}{ }^{-}$concentration (Fig. 1a, b), since there was a significant positive correlation coefficient $(r=$ $0.801 ; P=0.0304$ ) between these variables, indicating that the increase in proline in plants with $\mathrm{Cd}$ is associated to the increase in $\mathrm{NO}_{3}{ }^{-}$. On the other hand, it has been reported that to degradation of proteins by proteolytic enzymes [25] and the accumulation of this amino acid and formation of a non-toxic Cd-proline complex in tissues would be a plant response to reduce the phytotoxicity of the metal $[26,27]$. The increase of proline induced by $\mathrm{Cd}$ was evidenced in other forest species $[3,7,28]$.

The increase of TSC in $V$. surinamensis exposed to Cd (Fig. 3a, b) may have worked as a compatible solute, which would help the plant in the osmotic adjustment against Cd stress [24], i.e. the accumulation of TSC may have contributed to the maintenance of the water status of the plant, favoring tissue protection and physiological processes, which is an important mechanism in the tolerance of $V$. surinamensis to the presence of $\mathrm{Cd}$, at least during the experimental period. The results obtained in present study in relation to total soluble carbohydrates were evidenced by Anand et al. [23].

Sucrose is a disaccharide consisting of glucose and fructose and, by means of the invertase activity, plays an important metabolic role as a donor of glycosyl and fructosyl for the synthesis of polysaccharides [29] and amino acids in plants [30]. Therefore, the increase in sucrose concentration (Fig. 3c, d) in $V$. surinamensis exposed to $\mathrm{Cd}$ may be due to the inhibition of invertase activity, interfering with carbon and nitrogen metabolism, especially in proline accumulation (Fig. 2a, b). Another explanation for sucrose accumulation would be because the metal positively affects the activity of sucrose phosphate synthase (SPS) and negatively affects the sucrose synthase (SuSy) [31]. In addition, the increase in sucrose concentration in $V$. surinamensis exposed to $\mathrm{Cd}$ may be related to the degradation of starch by the 
activity of the enzymes $\alpha$ - and $\beta$-amylase hydrolases although heavy metals have an inhibitory effect on these enzymes [32]. The higher concentration of sucrose in the plant exposed to $\mathrm{Cd}$ could be related to a reduction in the cell metabolism of this carbohydrate [33] as a form of energy saving since sucrose accumulation in plants submitted to $\mathrm{Cd}$ would be a form of tolerance to the metal [8], which is attributed to chelation of $\mathrm{Cd}$ by sucrose. Thus, high concentrations of sucrose in $V$. surinamensis suggest a good metabolic regulatory state of the plant in the presence of $\mathrm{Cd}$. The high concentration of sucrose was also observed in other species of plants exposed to $\mathrm{Cd}[34,35]$.

The highest concentration of reducing sugars in plants under stress caused by $\mathrm{Cd}$ (Fig. 3e, f) indicates energy savings by plants or even the presence of $\mathrm{Cd}$ negatively affecting cell respiration of root and shoot. The results are consistent with those obtained by Xie et al. [9], who suggested the increase of reducing sugars due to the lower utilization of these carbohydrates in plants exposed to $\mathrm{Cd}$. The highest accumulation of reducing sugar in the root (Fig. 3e) suggests an increase in the transport of these carbohydrates from the shoot to the growing cells of the root system, indicating that $\mathrm{Cd}$ may not have affected the transport system of assimilates of $V$. surinamensis. In addition, the sugar transported to the roots because of starch degradation would be an essential energy substrate for the resumption of respiration, conferring a mechanism of tolerance of the plant against the phytotoxic effect of $\mathrm{Cd}$ [8]. Similar results in the reducing sugar concentration have been found in other species [36].

\section{Conclusion}

The effect of Cd was evidenced by the reduction of NR, ammonia, TSA and TSP activity, suggesting metal toxicity, at least in part, in the assimilation and nitrogen metabolism of $V$. surinamensis.

The increase in TSC, sucrose and proline, suggests a metabolic regulatory mechanism in $V$. sirinamensis in the presence of $\mathrm{Cd}$.

\section{Methods}

\section{Experiment location}

The experiment was conducted in a greenhouse at the Federal Rural University of Amazonia (UFRA) in Belém, State of Pará, Brazil. Belonging to the Institute of Agricultural Sciences with the following geographic coordinates $\left(01^{\circ} 27^{\prime} 21^{\prime \prime} \mathrm{S}, 48^{\circ} 30^{\prime} 16^{\prime \prime} \mathrm{W}\right)$ and in the established period from 15 September 2017 to 14 November 2017.

\section{Plant material and growth condition}

Seeds of $V$. surinamensis were collected in the area of the Brazilian Agricultural Research Corporation (Embrapa Eastern Amazon), located in Belém, State of Pará, Brazil $\left(01^{\circ} 26^{\prime} 44.2^{\prime \prime} \mathrm{S}, 48^{\circ} 25^{\prime} 03.8^{\prime \prime} \mathrm{W}\right)$. The identification and collection of seed samples for the experiment was carried out by the team of Dr. Eniel Cruz, a researcher at the Brazilian Agricultural Research Corporation, Agroforestry Research Center of the Eastern Amazon. To collect seeds from this area, authorization is not necessary as it is not a Forest Reserve. At the time of collection, no botanical sample was taken for the IAN Herbarium of Embrapa Amazônia Oriental because it is a very common species and is easily identified.

The identifications were carried out by the employees of Embrapa Amazônia Oriental, in relation to the verification of the samples, the herbarium of this institution is in quarantine due to COVID-19, with no expected return. Each country has its own rules of access to its genetic resources and in Brazil this access is more flexible for Universities and Research Institutions.

These seeds were sown in $5^{-} \mathrm{L}$ polyethylene trays containing sand and sterilized sawdust (1:1, v/v), and maintained under mean air temperature (Tair) and relative air humidity (RH) of $28^{\circ} \mathrm{C}$ and $90 \%$. After emergence, the seedlings containing the first pair of eophylls were transplanted to $10^{-} \mathrm{L}$ polyethylene pots containing yellow latosol and poultry litter $(3: 1, \mathrm{v} / \mathrm{v})$. The seedlings grown were in a greenhouse for 180 days, being irrigated daily to replace the water lost by evapotranspiration. Subsequently, the young plants were removed and their roots washed with deionized water and transferred to $5^{-} \mathrm{L}$ Leonard pots containing sterilized and washed sand and $800 \mathrm{~mL}$ of nutrient solution, replaced weekly and constituted of $(\mu \mathrm{M}): \mathrm{KH}_{2} \mathrm{PO}_{4}, 400 ; \mathrm{KNO}_{3}, 2000$; $\mathrm{Ca}\left(\mathrm{NO}_{3}\right)_{2}$ $4 \mathrm{H}_{2} \mathrm{O}, 2000 ; \mathrm{MgSO}_{4} \quad 7 \mathrm{H}_{2} \mathrm{O}, 800$; FeEDTA, 400; $\mathrm{H}_{3} \mathrm{BO}_{3}$, 400; $\mathrm{MnCl}_{2} 4 \mathrm{H}_{2} \mathrm{O}, 400 ; \mathrm{ZnCl}_{2}, 400 ; \mathrm{CuCl}_{2} 2 \mathrm{H}_{2} \mathrm{O}$, 400; and $\mathrm{H}_{2} \mathrm{MoO}_{4} \quad \mathrm{H}_{2} \mathrm{O}, 400$. The $\mathrm{pH}$ was maintained at $5.9 \pm 0.2$ using $\mathrm{HCl}$ and $\mathrm{NaOH}$. The ionic strength was initiated in $25 \%$ (10 days) and then increased to $50 \%$ (35 days), remaining for a period of acclimatization of 45 days.

\section{Experimental design and treatment evaluation}

After 45 days of cultivation, we selected the most uniform seedling considering height, stem diameter, number of leaves and submitted to five $\mathrm{Cd}$ concentrations (treatments) as following: $0 \mathrm{mg} \mathrm{L}^{-1}$ of $\mathrm{CdCl}_{2}$ (control), $15,30,45$, and $60 \mathrm{mg} \mathrm{L}^{-1}$ of $\mathrm{CdCl}_{2}$. The doses of $\mathrm{Cd}$ were determined based on the Resolution 420 of the National Council of the Environment, which establishes criteria and guiding values of soil quality regarding the presence of chemical substances. The experimental design was a completely randomized design with seven replications, per each treatment, totaling 35 experimental units. As ingle plant per pot was considered a replicate. All variables for treatment comparisons were assessed 60 days after $\mathrm{Cd}$ treatment differentiation. 


\section{Biochemical assessments}

The biochemical analyses were performed at the Laboratory of EBPS of UFRA. The following variables were determined: contents of nitrate $\left(\mathrm{NO}_{3}{ }^{-}\right)$and free ammonium $\left(\mathrm{NH}_{4}{ }^{+}\right)$ [37], activity of the enzyme nitrate reductase $\left(\mathrm{RNO}_{3}{ }^{-}\right)$[38]; total soluble amino acids (TSA) [39], total soluble proteins (TSP) [40]; proline [41], total soluble carbohydrates (TSC) [42]; sucrose [43]; and reducing sugars [44].

\section{Data analysis}

The experimental data were evaluated for normality and homogeneity of variances by the Shapiro-Wilk and Bartlett tests, respectively. The analyzes were performed using the SAS 9.1.3 software [45] and the Rstudio 1.1.383 software. For the parametric variables, the comparison of means was performed in PROC GLM, from SAS, with the method of least squares of adjustment of general linear models, with the MEANS instruction of multiple comparisons for means of main effect with the command lines tukey (Tukey's studentized range test (HSD). For the correlation analysis, the PROC CORR procedure, of the SAS, was used (Pearson lienar and Spearman moment product, for the parametric and nonparametric variables, respectively), the significance of these correlations was performed by the $t$ test. -student The Kruskal-Wallis test with Bonferroni correction was used for nonparametric variables in the control of Type I error, in RStudio. All statistical analyzes were performed at $5 \%$ significance level.

\section{Abbreviations \\ NR: Nitrate Reductase; TSA: Total Soluble Aminoacids; TSP: Total Soluble Proteins; TSC: Total Soluble Carbohydrates; Cd: Cadmium; AA: Aminoacids; ROS: Reactive Oxygen Species; SPS: Sucrose Phosphate Synthase; T air: Air; Temp: Temperature; $\mathrm{RH}$ : Relative Air Humidity; $\mathrm{NO}_{3}{ }^{-}$: Nitrate; $\mathrm{RNO}_{3}{ }^{-}$: Nitrate Reductase; DM: Dry Mass; FM: Fresh Mass; Glu: Glutamine; $\mathrm{NH}_{4}^{+}$: Ammonia; NRA: Nitrate Reductase Activity}

\section{Acknowledgments}

The authors are grateful to the Group of Studies on Biodiversity in Upper Plants of the Federal Rural University of Amazonia for the collaborations of researchers.

Coordination of the Improvement of Higher Education Personnel in Brazil (CAPES).

\section{Authors' contributions}

A.J.: Installation and application of experiment in a greenhouse; O. N.: and G.N: Biochemical analysis of the samples in a Plant Physiology laboratory; S. F.: production of data tables; E. C.: Collection of plant material (seeds) and storage; C. A.: Biochemical Analysis; S. V.: Statistical analysis of the data; V. B.: Translation of the scientific text; D. S and J. T.: Withdrawal of the greenhouse experiment. All authors have read and approved the manuscript.

\section{Funding}

not applicable.

\section{Declarations}

Ethics approval and consent to participate

not applicable.

\section{Consent for publication}

We consent to the publication of the manuscript for the journal BMC Plant Biology.

\section{Competing interests}

The authors declare that there is no conflict of interest publishing of the paper, that the paper has been not published elsewhere, and not include any form of plagiarism. All the authors mentioned above have approved the manuscript and have agreed with the submission of the manuscript.

\section{Author details}

${ }^{1}$ Federal Rural University of the Amazon, Institute of Agronomists Sciences, Campus Belém, Belém, Pará, Brazil. 'Brazilian Agricultural Research Corporation (Embrapa), Belem, Pará, Brazil. ${ }^{3}$ Museu Paraense Emílio Goeldi (MPEG), Belém, Brazil. ${ }^{4}$ Federal Rural University of the Amazon, Institute of Agronomists Sciences, Campus Parauapebas, Parauapebas, Pará, Brazil.

Received: 3 April 2020 Accepted: 3 March 2021

Published online: 24 March 2021

References

1. Zayneb C, Bassem K, Zeineb K, Grubb CD, Noureddine D, Hafedh M, Amine E. Physiological responses of fenugreek seedlings and plants treated with cadmium. Environ Sci Pollut Res. 2015;22(14):10679-89 https://doi.org/10.1 007/s11356-015-4270-8.

2. Elloumi N, Zouari M, Chaari L, Jomni C, Rouina BB, Abdallah FB. Ecophysiological responses of almond (Prunus dulcis) seedlings to cadmium stress. Biologia. 2014;69(5):604-9 https://doi.org/10.2478/s11756-014-0348-X.

3. He J, Li H, Luo J, Ma C, Li S, Qu L, Gai Y, Jiang X, Janz D, Polle A, Tyree M, Luo ZB. A Transcriptomic network underlies microstructural and physiological responses to cadmium in Populus $x$ canescens. Plant Physiol. 2013;162(1):424-39. https://doi.org/10.1104/pp.113.215681.

4. Nasraoui-Hajaji A, Chaffei-Haouari C, Ghorbel MH, Gouia H. Growth and nitrate assimilation in tomato (Solanum lycopersicon) grown with different nitrogen source and treated with cadmium. Acta Bot Gall. 2011;158(1):3-11 https://doi.org/10.1080/12538078.2011.10516249.

5. Nikolić N, Zorić L, Cvetković I, Pajević S, Borišev M, Orlović S, Pilipović A. Assessment of cadmium tolerance and phytoextraction ability in young Populus deltoides $\mathrm{L}$. and Populus $\mathrm{x}$ euramericana plants through morphoanatomical and physiological responses to growth in cadmium enriched soil. iForest. 2017;10(3):635-44. https://doi.org/10.3832/ifor2165-010.

6. Song $Y$, Jin L, Wang $X$. Cadmium absorption and transportation pathways in plants. Int J Phytoremediation. 2016;19(2):133-41. https://doi.org/10.1080/1 5226514.2016.1207598.

7. Wang Y, Gu C, Bai S, Sun Z, Zhu T, Zhu X, Grit DH, Tembrock LR. Cadmium accumulation and tolerance of Lagerstroemia indica and Lagerstroemia fauriei (Lythracaeae) seedlings for phytoremediation applications. Int J Phytoremediation. 2016;18(11):1104-12. https://doi.org/10.1080/15226514.2 016.1183581.

8. Rahoui S, Chaoui A, Bem C, Rickauer M, Gentzbittel L, Ferjani E. Effect of cadmium pollution on mobilization of embryo reserves in seedlings of six contrasted Medicago truncatula lines. Phytochem. 2015;111:98-106. https:// doi.org/10.1016/j.phytochem.2014.12.002.

9. Xie Y, Hu L, Du Z, Sun X, Amombo E, Fan J, Fu J. Effects of cadmium exposure on growth and metabolic profile of Bermudagrass [Cynodon dactylon (L.) Pers.]. PLoS One. 2014;9(12):e115279. https://doi.org/10.1371/ journal.pone.0115279.

10. Andrade Júnior WV, Oliveira Neto CF, Santos Filho BG, Amarante CB, Cruz ED, Okumura RS, Barbosa AVC, Sousa DJP, Teixeira JSS, Botelho AS. Effect of cadmium on young plants of Virola surinamensis. AoB Plants. 2019;11(3):111. https://doi.org/10.1093/aobpla/plz022.

11. Khan MA, Khan S, Khan A, Alam M. Soil contamination with cadmium consequences and remediation using organic amendments. Sci Total Environ. 2017;601-602:1591-605. https://doi.org/10.1016/j.scitotenv.201 7.06.030. 
12. Nascimento SF, Kurzweil H, Wruss W, Fenzl N. Cadmium in the Amazonian Guajara' estuary: distribution and remobilization. Environ Pollut. 2006;140(1): 29-42. https://doi.org/10.1016/j.envpol.2005.07.003.

13. Oliveira HSP, França SCA, Rocha EJP. Atividades de mineração e avaliação de metais em água superficial, sedimento de fundo e peixes no Rio Tapajós. In: Amazônia em tempo: estudos climáticos e socioambientais. Belém: Museu Paraense Emílio Goeldi / EMBRAPA; 2015. p. 195-222.

14. Dai H, Shan C, Jia G, Lu C, Yang T, Wei A. Cadmium detoxification in Populus x canescens. Turk J Bot. 2013;37(5):950-5. https://doi.org/10.3906/ bot-1110-9.

15. Mehes-Smith M, et al. Mobility of heavy metals in plants and soil: a case study from a mining region in Canada. Am J Environ Sci 9.6. 2013:483-93.

16. Hasanuzzaman M, Nahar K, Anee TI, Fujita M. Glutathione in plants: biosynthesis and physiological role in environmental stress tolerance. Physiol Mol Biol Plants. 2017;23(2):249-68. https://doi.org/10.1007/s12298-01 7-0422-2.

17. Hernández LE, Sobrino-plata J, Montero-Palmero MB, Carrasco-Gil S, FloresCáceres ML, Ortega-Villasante C, Escobar C. Contribution of glutathione to the control of cellular redox homeostasis under toxic metal and metalloid stress. J Exp Bot. 2015;66(10):2901-11. https://doi.org/10.1093/jxb/erv063.

18. Mao QQ Guan MY, LU KX, Du ST, Fan SK, Ye YQ, Lin XY, Jin CW. Inhibition of nitrate transporter 1.1-controlled nitrate uptake reduces cadmium uptake in Arabidopsis. Plant Physiol. 2014;166(2):934-44 doi. org/10.1104/pp.114.243766.

19. Van der Ent A, Baker AJM, Reeves RD, Pollard AJ, Schat H. Hyperaccumulators of metal and metalloid trace elements: facts and fiction. Plant Soil. 2013;362(1-2):319-34 https://doi.org/10.1007/s11104-012-1287-3.

20. Huang HE, Xiong ZT. Toxic effects of cadmium, acetochlor and bensulfuronmethyl on nitrogen metabolism and plant growth in rice seedlings. Pestic Biochem Physiol. 2009;94(2-3):64-7. https://doi.org/10.1016/j.pestbp.2009.04.003.

21. Zemanová V, Pavlík M, Pavlíková D, Tlustoš P. The changes of contents of selected free amino acids associated with cadmium stress in Noccaea caerulescens and Arabidopsis halleri. Plant Soil Environ. 2013;59(9):417-22. https://doi.org/10.17221/403/2013-PSE.

22. Dinakar P, Babu KG, Santhanam M. Corrosion behaviour of blended cements in low and medium strength concretes. Cem Concr Compos. 29.2. 2007:136-45.

23. Anand M, Kumar B, Sheel R. Effect of heavy metals on biochemical profile of Azolla filiculoides. Int J Curr Microbiol App Sci. 2017;6(10):3629-53 https:// doi.org/10.20546/ijcmas.2017.610.428.

24. Singh $S$, Parihar $P$, Singh $R$, Singh VP, Prasad SM. Heavy metal tolerance in plants: role of Transcriptomics, proteomics, metabolomics, and lonomics. Front Plant Sci. 2016;6:1-36. https://doi.org/10.3389/fpls.2015.01143.

25. Raldugina GN, Krasavina MS, Lunkova NF, Burmistrova NA. Chapter 4 resistance of plants to cu stress. Transgenesis. Plant Metal Interact. 2016:69114 https://doi.org/10.1016/B978-0-12-803158-2.00004-7.

26. Aslam R, Ansari MYK, Choudhary S, Bhat TM, Jahan N. Genotoxic effects of heavy metal cadmium on growth, biochemical, cyto-physiological parameters and detection of DNA polymorphism by RAPD in Capsicum annuum L. an important spice crop of India. Saudi J Bio Sci. 2014;21(5):46572. https://doi.org/10.1016/j.sjbs.2014.07.005.

27. Chen CT, Chen LM, Lin CC, Kao CH. Regulation of proline accumulation in detached rice leaves exposed to excess copper. Plant Sci. 2001;160(2):28390. https://doi.org/10.1016/s0168-9452(00)00393-9.

28. Yadav S, Srivastava J. Cadmium phytoextraction and induced antioxidant gene response in Moringa oleifera Lam. Am J plant Physiol. 2017;12(2):5870. https://doi.org/10.3923/ajpp.2017.58.70.

29. Sharma SS, Dietz KJ. The significance of amino acids and amino acidderived molecules in plant responses and adaptation to heavy metal stress. J Exp Bot. 2006;57(4):711-26. https://doi.org/10.1093/jxb/erj073.

30. Todd CD. Allantoin increases cadmium tolerance in Arabidopsis via activation of antioxidant mechanisms. Plant Cell Physiol Adv. 2016;57(12): 2485-96.

31. Fryzova R, Pohanka M, Martinkova P, Cihlarova H, Brtnicky M, Hladky J, Kynicky J. Oxidative stress and heavy metals in plants. In: de Voogt $P$, editor. Reviews of environmental contamination and toxicology (continuation of residue reviews), vol. 245. Madrid: Springer; 2017. p. 129-56. https://doi. org/10.1007/398_2017_7.

32. Reyes TH, Sartazza A, Pompeiano A, Ciurli A, Lu Y, Guglielminetti L, Yamaguchi J. Nitrate Reductase modulation in response to changes in $\mathrm{C} / \mathrm{N}$ balance and nitrogen source in Arabidopsis. Plant Cell Physiol. 2018;59(6): 1248-54. https://doi.org/10.1093/pcp/pcy065.

33. Badr A., Angers P., Desjardins P., 2015. Comprehensive analysis of in vitro to ex vitro transition of tissue cultured potato plantlets grown with or without sucrose using metabolic profiling technique. Plant Cell Tissue Organ Cult 122(2): 491-508. https://doi.org/10.1007/s11240-015-0786-3.

34. Devi R, Grupta AK, Murjral N, Kaur N. Cadmium induced changes in carbohydrate status and enzymes of carbohydrate metabolism, glycolysis and pentose phosphate pathway in pea. Environ Exp Bot. 2007;61(2):167-74 https://doi.org/10.1016/j.envexpbot.2007.05.006.

35. Kapoor D, Rattan A, Bhardwaj R, Kaur S. Photosynthetic efficiency, ion analysis and carbohydrate metabolism in Brassica juncea plants under cadmium stress. J Pharmacognosy Phytochemistry. 2016;5(3):279-86.

36. Shah K, Mankad AU, Reddy MN. Cadmium accumulation and its effects on growth and biochemical parameters in Tagetes erecta L. J Pharmacogn Phytochem. 2017;6(3):111-5 http://www.phytojournal.com/archives/2017/ vol6issue3/PartB/6-2-77-387.pdf.

37. Weatherburn MW. Phenol Hipochlorite reaction for determination of Ammonia. Anal Chem. 1967;39(8):971-4 https:/doi.org/10.1021/ac60252a045.

38. Hageman $\mathrm{RHG}$, Hucklesby DP. Nitrate Reductase from higher plants. Methods in Enzimol. 1971;23:491-503 https://doi.org/10.1016/S0076-6879(71 23121-9.

39. Peoples MB, Faizah AW, Reakasem BE, Herridge DF. Methods for evaluating nitrogen fixation by Nodulated legumes in the field. Aust Cent Int Agric Res Canberra. 1989;1:1-76. https://doi.org/10.22004/ag.econ.118041.

40. Bradford MM. A rapid and sensitive method for the quantitation of microgram quantities of protein utilizing the principle of protein-dye binding. Anal Biochem. 1976;72(1-2):248-54. https://doi.org/10.1006/abio.1 976.9999.

41. Bates LS, Waldren RP, Teare ID. Rapid determination of free Proline for water-stress studies. Short communication. Plant Soil. 1973;39(1):205-7 https://doi.org/10.1007/BF00018060

42. Dubois M, Gilles KA, Hamilton JK, Rebers PA, Smith F. Colorimetric method for determination of sugars and related substances. Anal Chem. 1956;28(3): 350-6 https://doi.org/10.1021/ac60111a017.

43. Van Handel E. Direct microdetermination of sucrose. Anal Biochem. 1968; 22(2):280-3 https://doi.org/10.1016/0003-2697(68)90317-5.

44. Rinner KT, Saurer M, Streit K, Siegwolf RTW. Evaluation of a liquid chromatography method for compound specific $\delta 13 \mathrm{C}$ analysis of plant carbohydrates in alkaline media. Rapid Commun Mass Spectrom. 2012; 26(18):2173-85 https://doi.org/10.1002/rcm.6334.

45. Statistical Analisys System Institute - SAS. SAS 9.1 .3 (TS1M3) for Windows Microsoft. Cary: SAS Institute Inc; 2007.

\section{Publisher's Note}

Springer Nature remains neutral with regard to jurisdictional claims in published maps and institutional affiliations.

Ready to submit your research? Choose BMC and benefit from:

- fast, convenient online submission

- thorough peer review by experienced researchers in your field

- rapid publication on acceptance

- support for research data, including large and complex data types

- gold Open Access which fosters wider collaboration and increased citations

- maximum visibility for your research: over $100 \mathrm{M}$ website views per year

At BMC, research is always in progress.

Learn more biomedcentral.com/submission 